\title{
EFFECT OF PREHARVEST FRUIT BAGGING ON QUALITY OF MANGO (MANGIFERAINDICA) CV. ALPHONSO
}

\author{
D. NAGAHARSHITHA ${ }^{1}$, P. M. HALDANKAR ${ }^{2} \&$ \\ ALASAHEBSAWANTKONKANKRISHIVIDYAPEET ${ }^{3}$
}

\begin{abstract}
Pre-harvest fruit bagging is emerging, as one of the new technologies for gaining fruits with very good quality. In the year 2012, an experiment was conducted in the months from March to June to study the effect of preharvest bagging on mango cv. Alphonso. This experiment was undertaken in Randomized Block Design. There were six types of bagging treatments in which the mango fruits are bagged in three replications at 60 days after fruit set. The present experiment concluded that the quality of mango fruit is influenced by the different types of bags. Incidence of stem end rot (\%) was found to be significantly higher (11.66\%) in $T_{7}$ (control) and it is observed to be the lowest (1.66\%) in $T_{5}$ (Muslin cloth bag) and $T_{6}$ (scurting bag). The highest sensory score for colour (8.20) was observed in $T_{5}$ (Muslin cloth bag) and was found to be the lowest (7.00) in $T_{3}$ (Butter cloth bag).The Highest sensory score for flavour (8.30) was found to be significantly higher in The $T_{6}$ (scurting bag) and found to be the lowest (6.94) in $T_{1}$ (Brown paper bag). The Highest sensory score for texture (7-56) was found to be in $T_{4}$ (Plastic bag) and seen to be the lowest (7.00) in $T_{3}$ (Butter paper bag). In the bagged fruits, there was no spongy tissue found. The most important benefit of all the bags over control is the reduction in the stem end rot disease incidence.
\end{abstract}

KEYWORDS: Alphonso, Bagging, Quality, Stem End Rot \& Spongy Tissue

Received: Sep 11, 2017; Accepted: Sep 25, 2017; Published: Oct 16, 2017; Paper Id.: IJASROCT201761

\section{INTRODUCTION}

Mango is one of the most important fruit crops in India. It is very delicious in taste and has an exceedingly acceptable flavour. It also has a very pleasing colour and has an exemplary nutritive value. Hence, mango is called, 'National fruit of India' and 'King of fruits'. "Alphonso" is locally called, "Hapus". This variety flourishes and gives the best yield, under humid and warm climate of Konkan region. It is especially preferred for exporting. It is because, of its optimum shape and size, exemplary flavour, very attractive golden yellow skin and its flesh colour. It is also because, of its good keeping qualities. For the table and processing purpose, it is the best variety (Cheema and Dani, 1934). In India, Alphonso is the most consumed table fruit. One of the most important parameters for its demand is, its external appearance. Generally, the fruits that look attractive, fetching premium rate in the market. To position the external appearance of a fruit, various approaches are followed. One of the novel ways among these various means is bagging of fruits.

Bagging is the procedure of covering individual fruits with specially designed cloth bags or paper bags. Bagging helps to protect fruits from fungal infections, pests, diseases, reduce insecticides spraying and mechanical damage. It also provides an estimation of the number of harvestable fruits on a tree. Bagging of fruits is also done for preventing the damage that could occur due to wounds, bruises, diseases, scars and pest attack. It also helps to produce cleaner fruit skin with impressive colours. 
Particularly, in mango, bagging plays an important role in preventing fungal disease incidence and fruit fly attack. Pre-harvest bagging has been found to show improvement in the quality of fruits. In addition, unfavourable climate is most often experienced in the Konkan region, which actually spoils the fruit's external appearance. In such conditions, bagging can be very helpful. Pre-harvest bagging has prospectus in an Alphonso variety of mango, which is not attempted much. Hence, this study was undertaken.

\section{MATERIALS AND METHODS}

This study was conducted in the Department of Horticulture, College of Agriculture, Dapoli (Maharashtra) during 20122013. This investigation helped to study the effect of bagging on the growth, development and Physio-chemical properties of mango. Fruit bagging was done on Alphonso fruits, in the mango orchard of Centre of Excellence project, Department of Horticulture, Dapoli (Maharashtra) India.

\section{Experimental Site}

This experiment was performed in the Indo Israel plot, Department of Horticulture, College of Agriculture Dapoli, Ratnagiri district. The soil used for experimental plot was red lateritic. It also had a uniform depth with favourable drainage conditions.

\section{Place and Weather Condition}

Dapoli is the place, which represents more or less tropical climate with $78 \%$ of humidity throughout the year. It has a minimum of $18.5^{\circ} \mathrm{C}$ and maximum $30.8^{\circ} \mathrm{C}$ temperature. It also has a precipitation of 3,500 mm on an average, which is distributed mainly during the months from June to September in a year. The Konkan region is located on the west coast of Maharashtra state, at $17^{\circ} 45^{\prime} \mathrm{N}$ latitude and $73^{\circ} 12^{\prime} \mathrm{E}$ longitude, with an altitude of $240 \mathrm{~m}$ from the MSL. The soil used for this experiment is sandy clay loam, lateritic and acidic in reaction with pH ranging from 5.6 to 6.5.

\section{Experimental Details}

The experimental details are given as under.

Experimental Design: Randomized Block Design (RBD)

No. of Replication: Three

No. of treatment: 7

No. of fruits/treatment/replication: 20

Stage of bagging: 60 days after fruit set

\section{Treatment Details}

\section{$\mathrm{T}_{1}$ : Brown paper bag}

$T_{2}$ : Newspaper bag

\section{$\mathbf{T}_{3}$ : Butter paper bag}

$\mathrm{T}_{4}$ : Plastic bag

$\mathrm{T}_{5}$ : Muslin cloth bag 


\section{$\mathrm{T}_{6}$ : Scurting bag}

\section{$\mathrm{T}_{7}$ : Control}

For the fruit develops, proper ventilation is required. Hence, perforations were made on all the bags except muslin cloth bags and scurting bags. For bagging purpose, egg sized fruits were selected. In the cases of more than two fruits in a cluster, the smaller deformed, underdeveloped, spotted fruits should be removed by secator and only the healthy fruits of 12 numbers are included in the bagging. For bagging, brown paper bags, butter paper bags, newspaper bags and plastic bags are also used. While bagging, these bags were stapled properly in order to protect them from falling down and also for ensuring that there will not be any open space that allows the insect entry and rain water. The muslin cloth bags and scurting bags were tied tightly with the help of thread.

\section{Pest and Disease Incidence}

Fruits are stored at ambient temperature conditions. All the fruits are examined thoroughly on alternate days for any visible symptoms of pest infection, spoilage and disease incidence.

The fruits are then harvested during 56-59 days of bagging. The fruits were then subjected to ripening under uniform room temperature conditions and $95 \%$ R. H.

After the fruits are ripening, the following observations are made.

\section{Incidence of Spongy Tissue (\%)}

After the fruits are ripening, each and every fruit that was subjected to the treatments were cut on the both sides of the stones. This was done to calculate the incidence of spongy tissue by using the following formula and expressed in percentage.

\section{Sensory-Evaluation}

When the fruits were ripe, they were examined for their sensory qualities. This was done to examine their flavour, texture and to access the colour. This examination was conducted by the panel of 5 judges with 9 points Hedonic scale score (Amerine et al., 1965) as given below.

By taking the average score of evaluation, the overall rating was obtained. The fruits that have scored 5.5 and above, were rated as acceptable.

\section{Statistical Analysis}

Statistical analysis was performed on the obtained data as per the methods suggested by Panse and Sukhatme (1985). Standard error of mean (S. Em.) was worked out and the calculation was made, on the critical difference (C. D.) at 5 per cent, whenever the results are found to be significant. The graphs and plates were used to support the important results.

\section{RESULTS AND DISCUSSIONS}


Incidence of Stem End Rot (\%)

Table 1 represents the data on the effect of bagging on incidence of disease stem end rot (\%) in mango fruits cv. Alphonso.

Table 1: Effect of Bagging on Incidence of Stem End Rot Disease (\%) in the Fruits of Mango cv. Alphonso

\begin{tabular}{|l|c|}
\hline \multicolumn{1}{|c|}{ Treatment } & Incidence of Stem End Rot (\%) \\
\hline $\mathrm{T}_{1}$ (Brown paper bag) & 3.33 \\
\hline $\mathrm{T}_{2}$ (Newspaper bag) & 3.33 \\
\hline $\mathrm{T}_{3}$ (Butter paper bag) & 3.33 \\
\hline $\mathrm{T}_{4}$ (Plastic bag) & 3.33 \\
\hline $\mathrm{T}_{5}$ (Muslin cloth bag) & 1.66 \\
\hline $\mathrm{T}_{6}$ (Scurting bag) & 1.66 \\
\hline $\mathrm{T}_{7}$ (control) & 11.66 \\
\hline Range & $1.66-11.66$ \\
\hline Mean & $\mathbf{4 . 0 4}$ \\
\hline S. Em \pm & 1.169 \\
\hline C. $\mathrm{D}$. at 5\% & 3.6 \\
\hline
\end{tabular}

Studies show that, the percentage of stem end rot disease being the highest in treatment $\mathrm{T}_{7}(11.66 \%)$. The treatments $\mathrm{T}_{5}$ and $\mathrm{T}_{6}(1.66 \%)$, showed the lowest stem end rot percentage. This result shows that, the stem end rot incidence has been significantly reduced by bagging.

As per the reports of Hofman et al. (1997), when a Keitt mango cultivar is bagged with white paper bags, Dothoriella induced stem end rot is reduced.

\section{Sensory Evaluation}

Table 2 presents the data regarding the effect of bagging on sensory evaluation of Alphonso mango fruits, during ripe stage.

Sensory score rating
9- Like extremely
6- Like slightly
3- Dislike moderately
8- Like very much
5- Neither like nor dislike
2- Dislike very much
7- Like moderately
4- Dislike slightly
1- Dislike extremely

Table 2: Effect of Bagging on Sensory Evaluation of Ripe Fruits in Mango cv. Alphonso

\begin{tabular}{|l|c|c|c|c|}
\hline \multirow{2}{*}{ Treatments } & \multicolumn{3}{|c|}{ Sensory Score for } & \multirow{2}{*}{ Average Score } \\
\cline { 2 - 4 } & Colour & Flavor & Texture & \\
\hline $\mathrm{T}_{1}$ (Brown paper bag) & 7.14 & 6.94 & 7.04 & 7.04 \\
\hline $\mathrm{T}_{2}$ (Newspaper bag) & 7.34 & 7.21 & 7.34 & 7.30 \\
\hline $\mathrm{T}_{3}$ (Butter paper bag) & 7.00 & 7.15 & 7.00 & 7.05 \\
\hline $\mathrm{T}_{4}$ (Plastic bag) & 7.50 & 7.40 & 7.56 & 7.49 \\
\hline $\mathrm{T}_{5}$ (Muslin cloth bag) & 8.20 & 7.54 & 7.40 & 7.71 \\
\hline $\mathrm{T}_{6}$ (Scurting bag) & 7.60 & 8.30 & 7.24 & 7.71 \\
\hline $\mathrm{T}_{7}$ (control) & 7.40 & 7.40 & 7.10 & 7.30 \\
\hline Range & $7.00-8.20$ & $6.94-8.30$ & $7.00-7.56$ & $7.04-7.71$ \\
\hline Mean & $\mathbf{7 . 4 5}$ & $\mathbf{7 . 4 2}$ & $\mathbf{7 . 2 4}$ & $\mathbf{7 . 3 7}$ \\
\hline S. Em \pm & 0.101 & 0.131 & 0.134 & 0.156 \\
\hline C. D. at 5\% & 0.312 & 0.404 & $\mathrm{NS}$ & 0.481 \\
\hline
\end{tabular}


When the colour of the bagged fruits was observed, it was found to be in the class of 'Like moderately' except the ones that were on the treatment $\mathrm{T}_{5}$. The fruits that were bagged with the treatment $\mathrm{T}_{5}$ were in the class of 'Like very much'.

When the sensory score of flavor was compared, it was found that all the treatment has the same class, i.e., 'Like moderately' class except the ones with the treatment $\mathrm{T}_{6}$.

The highest score was shown by the fruits of the treatment $\mathrm{T}_{6}$ and they were found to be in the class of 'Like very much'.

Similar to the score of the colour, the sensory score of the texture was found to be around 7 in all the fruits of all the treatments, thus indicating that, the texture of the fruits falls under the class of 'Like moderately'.

Therefore, the average of the sensory scores of all the treated fruits, including control fall under the class of 'Like moderately'.

\section{Occurrence of Spongy Tissue}

When compared with control, it was observed that, there is no occurrence of spongy tissue in all the bagged fruits.

\section{CONCLUSIONS}

The experiment concluded that these different types of bags influenced the quality of mango fruits. However, the effect was inconsistent.

The most important benefit of all the bags over control is the reduction of the stem end rot disease incidence. The sensory quality was found to be improved in the fruits of muslin cloth and scurting bags, which is beneficial to these bags. However, this is only the season study. In addition to these, when compared with control fruits, there is also no occurrence of the spongy tissue incident in bagged fruits. Further confirmation is required, which can be obtained by undertaking further research, on the various aspects of bagging.

\section{REFERENCES}

1. Amerine, M. A.; R. M. Pangborn and E. B. Rocssler (1965). Principles of sensory evaluation of food. Academic Press, London.

2. Cheema, G. S. and P. C. Dani (1934). Report on the export of mangoes to Europe, Dept. of Agril., Bombay Bull. No. 170.

3. Hofman, P. J.; L. G. Smith; D. C. Joyce; G. I. Johnson and G. F. Meiburg (1997). Bagging of mango (MangiferaindicaL.) cv. 'Keitt') fruit influences fruit quality and mineral composition. Postharvest biology and technology, 12(1): 83-91.

4. Panse, V. G. and P. V. Sukhatme (1995). Statistical methods for Agricultural Workers. ICAR Rev. Ed. By Sukhatme, P. V. and Amble, V. N. pp. 97-156. 

